\title{
Etiological and pathogenetic aspects of non-specific bacterial vaginosis
}

\author{
M. M. Ananieva \\ Higher State Educational Establishment of Ukraine “Ukrainian Medical Stomatological Academy”, Poltava
}

Key words: anaerobic bacteria, bacterial vaginosis, nonspecific vaginosis, pathogenesis.

Zaporozhye medical journal 2018; 20 (3), 432-436 DOI:

$10.14739 / 2310-1210$ 2018.3.132124

E-mail: anfila@ukr.net

The aim of this review was the biological properties analysis of microorganisms known as the main contributors to the non-specific bacterial vaginosis development.

The mechanisms of anaerobic vaginal microflora pathogenic action have been found out to be the main cause of non-specific inflammatory processes. Special attention was given to the genera of Mobilunkus spp., Atopobium spp., Prevotella sp. representatives, which were studied as vaginal flora due to the modern diagnostic methods and techniques development.

The homeostasis of the vaginal ecosystem results from complex interactions and synergies among the host and different microorganisms that colonize the vaginal mucosa and healthy vaginal microbiota is generally dominated by Lactobacillus spp. Lactobacilli which have been known to be antagonistic toward a variety of microorganisms.

In cases of bacterial vaginoses, the proportion of Lactobacilus spp sharply decreases, while the share of anaerobic microorganisms increases: Gardnerella vaginalis, Atopobium sp., Mobiluncus sp., Prevotella sp. The virulence factors of Gardnerella vaginalis pathogenicity are: its ability to form biofilms; the presence of genes responsible for cytotoxicity.

The ability of Gardnerella vaginalis, Atopobium sp., Mobiluncus sp., Prevotella sp. to produce short chain volatile fatty acids isomers results in the vaginal mucosa irritation (itching or burning) and discharge with unpleasant odour in BV associated with these microorganisms.

Atopobium vaginae, together with Mobiluncus spp. and Prevotella spp., provoke the accumulation of pro-inflammatory cytokines. The whole mechanism leads to an inflammation worsening in BV and stimulates the chronic process development.

Both microorganisms Mobiluncus spp. and $A$. vaginae are competitive lactobacilli in relation to the glycogen consumption.

Conclusions. Analysis of literature shows that pathogens of non-specific bacterial vaginosis have wide range of pathogenicity factors. This provides pathogenesis and clinical signs of the disease.

Киючові слова: анаеробна мікрофлора, бактеріальний вагіноз, неспецифічний вагіноз.

Запорізький медичний журнал. - 2018. -

T. 20, № 3(108), C. $432-436$

\section{Етіологічні та патогенетичні аспекти неспецифічного бактеріального вагінозу}

\section{М. М. Ананьєва}

Мета роботи - на основі відомостей фахової літератури виконати аналіз даних щодо біологічних властивостей мікроорганізмів, які є основними учасниками неспецифічного бактеріального вагінозу.

У результаті розкрито механізми патогенної дії анаеробної вагінальної мікрофрори як основної причини неспецифічних запальних процесів. Особливу увагу приділили представникам родів Mobilunkus spp., Atopobium spp., Prevotella sp., що вивчені як фрлора піхви завдяки розвитку сучасних методів дослідження.

Гомеостаз серед представників бактеріальної мікрофрлори в піхві підтримується завдяки антагонізму лактобацил щодо решти представників. У нормі лактобацили становлять 90 \% вагінальної мікрофрлори. Завдяки виділенню великої кількості кислот, підтримці рН на рівні 3,5-4,4, виділенню бактеріоцинів лактобацили стримують патогенну мікрофрлору.

При неспецифічних бактеріальних вагінозах різко зменшується частка Lactobacilus spp., збільшується кількість анаеробних мікроорганізмів Gardnerella vaginalis, Atopobium sp., Mobiluncus sp., Prevotella sp. Потужними фракторами патогенності Gardnerella vaginalis $є$ здатність до утворення біоплівки, наявність генів, що відповідають за цитотоксичність.Здатність Gardnerella vaginalis, Atopobium sp., Mobiluncus sp., Prevotella sp. до утворення летючих коротколанцюгових жирних кислот з ізомерами призводить до того, що при бактеріальних вагінозах, що викликані цими мікроорганізмами, з'являються подразнення слизових оболонок і виділення з неприємним запахом.

Бактерії роду Atopobium завдяки наявності специсічних ферментів здатні блокувати функцію системи комплементу (C5a i C1q). Atopobium vaginae разом із Mobiluncus spp. і Prevotella spp. викликає накопичення прозапальних цитокінів. Увесь механізм призводить до посилення запалення при бактеріальному вагінозі та стимулює розвиток хронічного процесу. Mobiluncus spp. i A. vaginae є конкурентами лактобацил щодо споживання глікогену.

Висновки. Аналіз фахової літератури вказує на наявність широкого спектра фракторів патогенності серед мікроорганізмів, що викликають неспецифічний бактеріальний вагіноз. Це зумовлює його патогенез, перебіг та особливості клінічних симптомів.

\section{Ключевые слова:} анаэробная микрофлора, бактериальный вагиноз, неспецифический вагиноз.

\section{Этиологические и патогенетические аспекты неспецифического бактериального вагиноза}

\section{М. Н. Ананьева}

Цель работы - на основе сведений специализированной литературы проанализировать данные о биологических свойствах микроорганизмов, основных участниках неспецифического бактериального вагиноза.

На основании научной литературы раскрыты механизмы патогенного действия анаэробной влагалищной микрофлоры как основной причины неспецифических воспалительных процессов. Особое внимание уделено представителям родов 
Mobilunkus spp., Atopobium spp., Prevotella sp., которые изучены как фрлора влагалища благодаря развитию современных методов исследования.

Гомеостаз среди представителей бактериальной микрофлоры во влагалище поддерживается благодаря антагонизму лактобацилл по отношению к остальным представителям. В норме лактобациллы составляют 90 \% вагинальной микрофрлоры. Благодаря выделению большого количества кислот, поддержанию рН на уровне 3,5-4,4, выделению бактериоцинов лактобациллы сдерживают патогенную микрофлору.

При бактериальных вагинозах резко уменьшается доля Lactobacilus spp. и увеличивается количество анаэробных микроорганизмов Gardnerella vaginalis, Atopobium sp., Mobiluncus sp., Prevotella sp. Мощными факторами патогенности Gardnerella vaginalis являются способность к образованию биопленки, наличие генов, отвечающих за цитотоксичность.

Способность Gardnerella vaginalis, Atopobium spp., Mobiluncus sp., Prevotella spp. к образованию летучих короткоцепочечных жирных кислот с изомерами приводит к тому, что при бактериальных вагинозах, вызванных этими микроорганизмами, появляются раздражение слизистых оболочек и выделения с неприятным запахом.

Бактерии рода Atopobium благодаря наличию специфических ферментов способны блокировать функцию системы комплемента (С5a и C1q). Atopobium vaginae совместно с Mobiluncus spp. u Prevotella spp. провоцирует накопление провоспалительных цитокинов. Весь механизм приводит к усилению воспаления при бактериальном вагинозе и стимулирует развитие хронического процесса.

Mobiluncus spp. и A. vaginae. - конкуренты лактобацилл по отношению к потреблению гликогена. Микроорганизмы рода Mobiluncus обладают таким ферментом агрессии, как нейраминидаза.

Выводы. Анализ научной литературы указывает на наличие широкого спектра фракторов патогенности микроорганизмов, которые принимают участие в развитии неспецифического бактериального вагиноза. Это обусловливает его патогенез, течение и особенности клинических симптомов.

\section{Actuality}

Bacterial vaginosis, also known as vaginal bacteriosis, is a non-specific inflammatory process caused by the combined action produced by bacterial microflora, microbiota composition imbalance with the anaerobic microflora predominance that can lead to serious reproductive health consequences for women

Shift in the qualitative and quantitative composition of vaginal microbiota (a decrease in the number of facultative anaerobic lactobacilli and an increase in the number of anaerobic bacteria) now is associated with a variety of causes, including irregular use of antibiotics, alcohol consumption, smoking, and having sex with different partners (more than 3 persons a year) [1]. Moreover, acquired immunodeficiency conditions, diabetes mellitus, thyroid disorders, chronic inflammatory processes contribute not only to a decrease in the body reactivity, but also to a change in the $\mathrm{pH}$ of biological fluids that in turn potentiates increased proliferation of opportunistic microflora and the development of pathological inflammatory processes [2-5].

An important factor for the restoration of vaginal microflora is an imbalance in the level of sex hormones which regulate the composition and thickness of the vaginal mucous membrane. Equilibrium can be impaired by incorrect prescription or incorrect use of contraceptives as well as may develop in the post-menopausal period [6]

$\mathrm{BV}$, in turn, can cause inflammatory diseases of the female genital organs, endometriosis, endometritis $[7,8]$, salpingitis that can result in premature pregnancy termination, or infertility [9]. Bacterial vaginosis enhance the risk of infection with viruses, HIV infection and other sexually transmitted infections [6].

Nowadays the resistance of the BV causative agents to metronidazole as the main antibacterial agent is one of challenge facing the practical healthcare. In light of this, the biological characteristics of $\mathrm{BV}$ main causative agents and the influence of their properties on the pathogenesis and clinical picture determine the relevance of the study.

\section{The aim}

The aim of this review is the identification and description of microorganisms' biological properties, known as agents of bacterial vaginoses, and their contribution into the pathogenesis of this condition.

Vaginal microflora is a fairly constant biotope, $90 \%$ of which is represented by aerobic and facultative anaerobic microflora, mainly by Lactobacillus sp. $\left(10^{7}-10^{8}\right)[10]$.

Lactobacilli belong to the family Lactobacillaceae, genus Lactobacillus. At present, 120 species of lactobacilli have been identified, which are divided into 6 types according to their DNA structure (based on the DNA hybridization method). The vaginal lactobacilli are predominantly represented by L. acidophilus type, or more precisely, by 4 species: L. crispatus, L. jensenii, L. gasseri, L. iners. The fact that one or the other species predominate among women of different races [11] requires a more detailed study.

Lactobacilli are Gram-positive rod-shaped or slightly curved facultative anaerobic or organotrophic. In smears they may be in singles, in pairs or in short chains, immobile, non-spore-forming, non-capsule-formin; bacteria subjected to Gram staining contain cytoplasmic granules [12].

The quantitative and specific composition of vaginal lactobacilli has been known as hormone-dependent. Estrogens stimulate glycogen production and the formation of receptors for lactobacilli on the surface of epithelial cells. Glycogen, in turn, is the energy and nutrient substrate for bacteria of the genus Lactobacillus. In the process of their vital functioning and glycogen synthesis, lactobacilli produce a large amount of acids (lactic, succinic, butyric, acetic) that helps maintain $\mathrm{pH}$ 3.5-4.4 [11]. Besides the acids, the bacteria release $\mathrm{CO}_{2}$ and $\mathrm{H}_{2} \mathrm{O}_{2}$. The interaction between $\mathrm{H}_{2} \mathrm{O}_{2}$, chlorides released by lactobacilli, and myeloperoxidase (a product of lymphocytes) generates hypochloric acid, which exerts bactericidal properties.

Moreover, lactobacilli cell wall antigens stimulate the cellular and humoral local immunity by leukocytes, macrophages activation and IgA production. Under conditions
Запорожский медицинский журнал. - 2018. -

T. 20, № 3(108). C. $432-436$ 
of microbial antagonism, lactobacilli secrete bacteriocins (lactacidin, acidodicin), which prevent the spread of pathogenic microflora [13]. The combined effect of the above mentioned factors and the fact that Lactobacilus spp. has no pathogenicity factors contribute to maintaining homeostasis (colonization resistance) of the vaginal biotope [4].

With bacterial vaginosis the proportion of Lactobacilus spp. representatives sharply decreases and the amount of anaerobic microorganisms Gardnerella vaginalis (98-100 \%) increases: Atopobium sp., Mobiluncus sp., Prevotella sp. up to $10^{8}-10^{10}$, the ratio between anaerobes and aerobes is 100:1-1000: 1 ; there is no or reduced concentration of Lactobacillus sp., about $10^{4}-10^{5}$ bacteria/ml [1] .

Gardnerella vaginalis was first described in the mid-50s of the XX century and due to the works of $\mathrm{H}$. Gardner has been thought to be the predominant microorganism associated with bacterial vaginosis. Atopobium sp., Mobiluncus $s p$., Prevotella sp. have been described in details during the last two decades. These microorganisms are difficult to cultivate and their isolation is directly related to the development of modern identification methods and techniques.

The use of polymerase chain reaction (PCR) in the diagnosis of bacterial infections has considerably expanded the doctors' view on the species composition of all biotopes of the human body, including the female genitourinary system. The discovery of $16 \mathrm{~S}$ rRNA enables to study the qualitative and quantitative composition of healthy women microbiota and at different stages of bacterial vaginosis [14]. Later, scientists developed conditions and cultivation methods of conditionally pathogenic anaerobic microorganisms which can cause inflammatory diseases of female reproductive system.

Gardnerella vaginalis is a facultative anaerobic Gram-variable rod sized of 0.5-1.5 $\mu \mathrm{m}$. In smears taken form the clinical material it looks like a coccal bacterium. Usually, it is pleomorphic gram-negative to gram-variable bacteria; immobile; non-spore-forming, non-capsule-formin . Being a facultative anaerobic bacterium during cultivation it prefers $5-10 \% \mathrm{CO}_{2}$, is fastidious about the composition of the nutrient medium. Optimum required temperature is $35-37^{\circ} \mathrm{C}$. On the blood agar with adding of human erythrocytes the microorganisms grow into small colourless semitransparent colonies with the $\beta$-hemolysis zone. The microorganisms are catalase- and oxidase-negative; have a fermentative type of metabolism, inhibit $\mathrm{H}_{2} \mathrm{O}_{2}$, which is actively released by lactobacilli; hydrolyze starch, dextrin, maltose, ribose forming short chain volatile fatty acids with isomers (fractions C2-C6), mainly acetic C2. These compounds produce unpleasant smell of rotten fish $[1,12]$

An influential factor in the pathogenicity of Gardnerella vaginalis is its adhesive ability, which enables bacteria to attach to the epithelium of the vaginal mucosa, colonize it and form a biofilm [15]. In experiments with the clinical material taken from 30 patients it has been shown that Gardnerella acts as the primary colonizer and probably contributes to the attachment of other opportunistic microorganisms [16]. On the other hand, in bacterial vaginosis, there have been isolated strains of Gardnerella vaginalis with vaginolysin (vly) virulence genes responsible for bacterial cytotoxicity. Adhesive ability was studied in experiments on HeLa cell cultures. The experiment demonstrated how Gardnerella displaced previously attached lactobacilli from epithelial cells. The authors suggested that the increased virulence was not directly related to the accumulation of biofilm, but depended on the presence of $G$. vaginalis subspecies, which had additional virulence factors $[17,18]$.

$\mathrm{R}$. Verhelst et al. published their report on the isolation (during the cloning of genes 16s rRNA) of Atopobium vaginae in association with Gardnerella vaginalis in vaginoses of I, II, III degrees [19]. Later studies of Swidsinski et al. [20] confirmed that $1-40 \%$ of the mass of biofilm in the clinical material were made up of Atopobium vaginae. Recent studies of the bacterial vaginosis etiology have shown that Atopobium vaginae is found in microbial associations in $80 \%$ to $95 \%$ of cases [21, 22].

Bacteria of genus Atopobium sp. in the family Coriobacteriaceae were first described in 1992 by Rodriguez et al. Earlier representatives of this genus were classified as lactobacilli by morphological and biochemical characteristics (the ability to release a large amount of lactic acid). Subsequently, by using molecular genetic methods it was found that the 16s rRNA gene of $A$. vaginae differed from other species belonging to a genus of Atopobium approximately by 3-8 \% [23]. H. Mendes-Soares et al. in their research [24] based on the above method, have found the taxonomic diversity of representatives of the genus Atopobium in the vaginal secretions.

A. vaginae is a Gram-positive anaerobic rod of $0.5-1.2$ $\times 1.0-5.0 \mu \mathrm{m}$, sometimes resembles coccobacilli. In the field of view the microorganisms are located in singles, in pairs or in short chains $[12,23]$.

A. vaginae are classified as hard-to-cultivate microflora. On blood agar under strictly anaerobic conditions in 48 hours they grow into small gray-white colonies raised above the nutrient medium $[19,23]$.

A. vaginae had a fermentative type of metabolism with a large amount of volatile amines formation (methylamine, dimethylamine, trimethylamine, etc.) and short chain volatile fatty acids (C18: 1 - cis-vaccenic) that can explain unpleasant odor of vaginal discharge caused by anaerobic microorganisms [1,12].

The anaerobic respiration of the bacteria of the genus Atopobium involves the glycolytic pathway which is carried out through numerous enzymes. In this way, the enzyme D-glyceraldehyde-3-phosphate dehydrogenase (GAPDH) acts as a pathogenicity factor blocking the complement system (C5a and C1q) function [21].

According to the reports of Onderdonk A. B. et al. [25] the main pro-inflammatory tumour-necrosis factor, as well as the pro-inflammatory cytokines IL8, MIP-3a activation in vaginal epithelial cells under the influence of $A$. vaginae, plays an important role in the BV pathogenesis (an important pathogenetic aspect). Moreover, in case of Trichomonas vaginalis infection, Atopobium enters into close interaction with this pathogen, and is absorbed by epithelial cells that makes it inaccessible to antibiotics and increases the risk of disease recurrence [25].

One of the potential markers of bacterial vaginosis is opportunistic microorganisms of the genus Mobiluncus, family of Actinomycetaceae: Mobiluncus curtisii curtisii, Mobiluncus curtisii holmesii and Mobiluncus mulieris. They are found not only in healthy women, but also in patients with endometritis, chorioamnionitis, bacterial vaginosis $[25,26]$, because of Lactobacillus spp. replacement by Mobilincus spp. [27]. 
Mobiluncus spp. are anaerobic thin curved rods of $0.4-0.6 \times 1.2-4.0 \mu \mathrm{m}$, narrow-ended and different in their shape and size. In the field of view they are located in singles or in pairs in the form of gull wings. Tinctorial properties are variable, but the cell wall is of Gram-positive type [12]. They are motile due to numerous flagella. The optimum growth temperature is $37^{\circ} \mathrm{C}$. On complex nutrient media with the addition of blood serum of a rabbit or a horse they form colorless, transparent, smooth, convex colonies. Like $A$. vaginae, they have a fermentative type of metabolism. The products of glucose fermentation are acetate and succinate $[12,25]$. They compete with lactobacillus in relation to the glycogen consumption [25]. The ability of Mobiluncus spp. to form succinic acid and trimethylamine results in irritation of vaginal lining and discharge with unpleasant odor in BV associated with these microorganisms [28]. Culhane J. F. et al. show the presence of such aggressive enzymes as neuraminidase in the genus Mobiluncus microorganisms [18].

Like Atopobium vaginae, Mobiluncus spp. provokes the accumulation of pro-inflammatory cytokines IL-1 $\alpha, \mathrm{IL}-1 \beta$, TNF- $\alpha$ and IL-8, which increase the inflammation severity [32]. H. Girerd considers that the IL-1 $\beta$ amount assessment the vaginal fluid is a more sensitive test than the clinical signs for BV diagnosis [30].

Microorganisms of the genus Prevotella, especially in association with Gardnerella vaginalis, are quite often detected in bacterial vaginosis [30]. This microorganism is mainly known as an etiological factor of periodontal diseases [33]. The family Prevotellaceae, the genus Prevotella (formerly called Bacteroides) includes a variety of species inhabiting the human mucous membranes, most often it is intestine, oral cavity, vagina and respiratory tract. Most of the representatives are commensal, but in association with other microorganisms or in the optimum growth conditions, Prevotella spp. may cause inflammatory and purulent processes [31].

Prevotella spp. is Gram-negative rod-shaped microorganisms prone to polymorphism. In the field of view the microorganisms are arranged chaotically or in small clusters, they have a thin capsule. Many species have pili, which promote bacterial adhesion to and penetration into epithelial cells [12]. They are obligate anaerobes, nutritionally fastidious. In culture with $5 \%$ blood agar they grow into small, dark colonies in 4-5 days.

Bacteria of the genus Prevotella secrete a large number of hydrolytic enzymes: cysteine protease promotes the suppression of the C3 complement factor [32]; IgA proteases destroy $\lg \mathrm{A} 1$ and $\lg \mathrm{A} 2$, which are the factors of primary immune defense [33]. In severe inflammatory processes additional nutrients for Prevotella spp. are released from the tissue that promotes their rapid growth. Furthermore, to obtain hemin and vitamin K, Prevotella spp. penetrates to epithelial cells, where it becomes inaccessible to immune defense factors [33].

Larsen J. M. in his work has demonstrated that a potent pathogenicity factor is the cell wall lipopolysaccharide (LPS) of Prevotella spp. LPS activates macrophages for IL-1 1 IL6 , IL-23 production. These substances stimulate Th17 to release IL-17, which is opsonin for neutrophils. The whole mechanism leads to an increase in inflammatory response to BV and promotes the chronic process development [31].

At the same time, macrophages release IL-12, which activates Th1. Additional CCL5 receptors expression on the Th1 membrane is regarded as a risk factor associated with HIV infection [31].

\section{Conclusions}

Thus, the endogenous and exogenous factors influence can significantly affect the state of vaginal homeostasis. Once there are the qualitative and quantitative abnormalities of lactobacilli composition, there is growth of microorganisms with pathogenicity factors sufficient to develop local or generalized inflammation.

Due to their biological characteristics Atopobium sp., Mobiluncus sp. and Prevotella sp. involve the host's immune system factors into the pathological process (lead to a "surge" of cytokines and other pro-inflammatory factors) that contributes to subsequent tissue damage.

Prospects for further research. The ability to parasitize inside epithelial cells makes these microorganisms inaccessible to traditional BV therapy, thus, motivating the search for new therapeutic agents that do not affect lactobacilli.

Conflicts of Interest: author has no conflict of interest to declare. Конфлікт інтересів: віАсутній.

Information about author:

Ananieva M. M., MD, PhD, Associate Professor of the Department of Microbiology, Virology and Immunology, HSEEU “Ukrainian Medical Stomatological Academy", Poltava.

Відомості про автора:

Ананьєва М. М., канА. меА. наук, Аоцент каф. мікробіології, вірусології та імунології, ВАНЗУ „Українська меАична стоматологічна академія", м. Полтава.

\section{Сведения об авторе:}

Ананьева М. Н., канА. меА. наук, Аоцент каф. микробиологии, вирусологии и иммунологии, ВГУзУ «Украинская меАицинская стоматологическая академия", г. Полтава.

Надійшла Ао редакції / Received: 03.11.2017

Після Аоопрацювання / Revised: 01.12.2017

Прийнято Ао Аруку / Accepted: 06.12.2017

\section{References}

[1] Badyigina, N., Kostiuk, S., Shimanskaya, I., Rudenkova, T., \& Poluyan, O. (2014). Laboratornaya diagnostika bakterial'nogo vaginoza - ocenka sostoyaniya vlagalischnogo biotopa [Bacterial vaginosis laboratory diagnostics - vaginal biotope status estimation]. Laboratornaya diagnostika. Vostochnaya Evropa, 1(09), 112-11. [in Russian].

[2] Hirji, I., Andersson, S. W., Guo, Z., Hammar, N., \& Gomez-Caminero, A. (2012). Incidence of genital infection among patients with type 2 diabetes in the UK General Practice Research Database. Journal of diabetes and its complications, 26(6), 501-505. doi: 10.1016/j. jdiacomp.2012.06.012.

[3] Xu, M.-Q., Cao, H.-L., Wang, W.-Q., Wang, S., Cao, X.-C., Yan, F., et al. (2015). Fecal microbiota transplantation broadening its application beyond intestinal disorders. World Journal of Gastroenterol, 21(1), 102-111. doi: 10.3748/wjg.v21.i1.102.

[4] Rishchuk, S. V. (2016). Disbioz vlagalischa: novyj vzglyad na problemu [Vaginal dysbiosis: a new look at the problem]. Voprosy ginekologii, akusherstva i perinatologii, 15(3), 54-63. [in Russian].

[5] Faustova, M. O., Nazarchuk, O. A., \& Ananieva, M. M. (2017). Etiolohichna struktura, biolohichni vlastyvosti dominuiuchykh zbudnykiv peryimplantatnoho mukozytu [The etiological structure, biological properties of causative agents of peri-implant mucositis]. Zaporozhye medical journal, 19, 5(104), 652-657. doi: 10.14739/2310-1210.2017.5.110226 [in Ukrainian]. 
[6] Moncla, B. J., Chappell, C. A., Debo, B. M., \& Meyn, L. A. (2016). The Effects of Hormones and Vaginal Microflora on the Glycome of the Female Genital Tract: Cervical-Vaginal Fluid. PLOS ONE, 11(7), e0158687. doi: 10.1371/journal.pone.0158687.

[7] Khan, K. N., Fujishita, A., Kitajima, M., Hiraki, K., Nakashima, M., \& Masuzaki, H. (2014). Intra-uterine microbial colonization and occurrence of endometritis in women with endometriosist. Human reproduction, 29(11), 2446-2456. doi: 10.1093/humrep/deu222.

[8] Voronin, K. V., Alale, A. M., Alale, I. I., \& Chervonyi, S. I. (2015). Aktivnaya profilaktika poslerodovogo e'ndometrita u beremennykh s anae'robnym disbiozom i planiruemym kesarevym secheniem [Active prevention of postpartum endometritis in pregnant women with anaerobic dysbiosis and planned cesarian section]. Klinichna medytsyna, 20(3), 42-47. [in Russian].

[9] Taylor, B. DeP., Darville, T., \& Haggerty, C. L. (2013). Does Bacterial Vaginosis Cause Pelvic Inflammatory Disease? Sexually Transmitted Diseases, 40(2), 117-122. doi: 10.1097/OLQ.0b013e31827c5a5b.

[10] Mishin, V. V., Gricenko, L. Z., Anan'eva, M. N., \& Shipov. D. (2012). Probiotiki [Probiotics]. Doneck. [in Russian].

[11] Budilovskaya, O. V. (2016). Sovremennye predstavleniya o laktobacillakh vlagalischa zhenschin reproduktivnogo vozrasta [Current views on vaginal lactobacilli in women of reproductive age]. Zhurnal akusherstva i zhenskikh boleznej, 65(4), 34-43. [in Russian]. doi: 10.17816/ JOWD65434-43.

[12] Hole, J., Krieg, N., Snyt, P., Staley, J., \& Williams, (Eds.). (1997). Opredelitel' bakterij Berdzhi [The determinant of Berjee bacteria]. (Vols. 1). Moscow: Mir. [in Russian].

[13] Bondarenko, V. M., \& Bondarenko, K. R. (2014). Vaginal'naya mikroe'kosistema $v$ norme i patologii [The vaginal microecosystem in norm and pathology]. Byulleten' Orenburgskogo nauchnogo centra URO RA, 1. [in Russian].

[14] Clark, N., Tal, R., Sharma, H., \& Segars, J. (2014). Microbiota and Pelvic Inflammatory Disease. Seminars in Reproductive Medicine, 32(01), 043-049. doi: 10.1055/s-0033-1361822.

[15] Shalepo, K. V., Mihailenko, T. G., \& Savicheva, A. M. (2016). Rol' bakterial'nykh plenok $\mathrm{v}$ formirovanii khronicheskikh patologicheskikh processov vo vlagalische i e'ndometrii [The role of bacterial biofilms in the development of chronic pathological processes in the vagina and endometrium]. Zhurnal akusherstva i zhenskikh boleznej, 65(4), 65-75. [in Russian]. doi: 10.17816/JOWD65465-75.

[16] Stanley, N. R., \& Lazazzera, B. A. (2004). Environmental signals and regulatory pathways that influence biofilm formation. Molecular Microbiology, 52, 917-924. doi: 10.1111/j.1365-2958.2004.04036.x.

[17] Castro, J., Alves, P., Sousa, C., Cereija, T., França, A., Jefferson, K. K., \& Cerca, N. (2015). Using an in-vitro biofilm model to assess the virulence potential of bacterial vaginosis or non-bacterial vaginosis Gardnerella vaginalis isolates. Scientific reports, 5, 11640. doi: 10.1038/ srep11640.

[18] Machado, A., \& Cerca, N. (2015). Influence of Biofilm Formation by Gardnerella vaginalis and Other Anaerobes on Bacterial Vaginosis. The Journal of Infectious Diseases, 212(12), 1856-1861. doi: 10.1093/ infdis/jiv338.

[19] Verhelst, R., Verstraelen, H., Claeys, G., Verschraegen, G., Delanghe, J., Simaey, L. V., et al. (2004). Cloning of 16 S rRNA genes amplified from normal and disturbed vaginal microflora suggests a strong association between Atopobium vaginae, Gardnerella vaginalis and bacteria vaginosis. BMC Microbiology, 4, 16. doi: 10.1186/1471-2180-4-16

[20] Swidsinki, A., Mendling, W., Loening-Baucke, V., Ladhoff, A., Swidsinki, S., Hale, L. P., \& Lochs H. (2005). Adherent biofilms in bacterial vaginosis. Obstetrics \& Gynecology, 106, 1013-1023. doi: 10.1097/01. AOG.0000183594.45524.d2.

[21] Querol-García, J., Fernández, F. J., Marin, A. V., Gómez, S., Fullà, D., Melchor-Tafur, C., et al. (2017). Crystal Structure of Glyceraldehyde-3-Phosphate Dehydrogenase from the Gram-Positive Bacterial Pathogen A. vaginae, an Immunoevasive Factor that Interacts with the Human C5a Anaphylatoxin. Frontiers in Microbiology, 8, 541. doi: 10.3389/fmicb.2017.00541.

[22] Hardy, L., Jespers, V., Abdellati, S., De Baetselier, I., Mwambarangwe, L., Musengamana, V., et al. (2016). A fruitful alliance: the synergy between Atopobium vaginae and Gardnerella vaginalis in bacterial vaginosis-associated biofilm. Sexually transmitted infection, 92(7), 487-491. doi: 10.1136/sextrans-2015-052475.

[23] Polatti, F. (2012). Bacterial Vaginosis, Atopobium vaginae and Nifuratel. Current Clinical Pharmacology, 7(1), 36-40. doi: 10.2174/157 488412799218824

[24] Mendes-Soares, H., Krishnan, V., Settles, M. L., Ravel, J., Brown, C. J., \& Forney, L. J. (2015). Fine-scale analysis of $16 \mathrm{~S}$ rRNA sequences reveals a high level of taxonomic diversity among vaginal Atopobium spp. Pathogens and Disease, 73(4), ftv020. doi: 10.1093/femspd/ftv020.

[25] Onderdonk, A. B., Delaney, M. L., \& Fichorova, R. N. (2016). The Human Microbiome during Bacterial Vaginosis. Clinical Microbiology Reviews, 29(2), 223-238. doi: 10.1128/CMR.00075-15.
[26] Zubkov, M. N. (2005). Sovremennaya taksonomiya i nomenklatura obligatno-anae'robnykh bakterij, vydelennykh ot cheloveka [Modern Taxonomy and Classification of Anaerobic Bacteria]. Klinicheskaya mikrobiologiya $i$ antimikrobnaya khimioterapiya, 7(4), 312-322. [in Russian].

[27] Anahtar, M. N., Byrne, E. H., Doherty, K. E., Bowman, B. A., Yamamoto, H. S., Soumillon, M., et al. (2015). Cervicovaginal bacteria are a major modulator of host inflammatory responses in the female genita tract. Immunity, 42(5), 965-976. doi: 10.1016/j.immuni.2015.04.019.

[28] Africa, C. W. Nel, J. \& Stemmet, M. (2014). Anaerobes and bacteria vaginosis in pregnancy: virulence factors contributing to vaginal colonisation. International Journal of Environmental Research and Public Health, 11, 6979-7000. doi: 10.3390/ijerph110706979.

[29] Anahtar, M. N., Byrne, E. H., Doherty, K. E., Bowman, B. A., Yamamoto, H. S., Soumillon, M., et al. (2015). Cervicovaginal bacteria are a major modulator of host inflammatory responses in the female genital tract. Immunity, 42(5), 965-976. doi: 10.1016/j.immuni.2015.04.019.

[30] Girerd, P. H., \& Rivlin, M. E. (Eds.). (2016). Bacterial Vaginosis. Retrieved from http://emedicine.medscape.com/article/254342-overview.

[31] Larsen, J. M. (2017). The Immune Response to Prevotella Bacteria in Chronic Inflammatory Disease. Immunology, 151(4), 363-374. doi: $10.1111 / \mathrm{imm} .12760$.

[32] Potempa, M., Potempa, J., Kantyka, T., Nguyen, K. A., Wawrzonek, K, Manandhar, S. P., et al. (2009). Interpain A, a Cysteine Proteinase from Prevotella intermedia, Inhibits Complement by Degrading Complement Factor C3. PLOS Pathogens, 5(2), e1000316. doi: 10.1371/journal. ppat.1000316.

[33] Prevotella intermedia. Techne qPCR test. 150 tests. For general laboratory and research use only. 1. Quantification of Prevotella intermedia genomes. Retrieved from www.techne.com/docs/p_intermedia.pdf. 